\title{
Acts of pedagogical resistance: Marking out an ethical boundary against human technologies
}

Policy Futures in Education

$0(0) 1-15$

(C) The Author(s) 2021

(c) (i)

Article reuse guidelines: sagepub.com/journals-permissions DOI: | 0.1 | 77// 4782 | 0320976978

journals.sagepub.com/home/pfe

(SAGE

\section{Lynn J McNair (D)}

Institute of Education, Community and Society, University of Edinburgh,

Scotland

\section{Caralyn Blaisdell}

Division of Psychology, Sociology and Education, Queen Margaret

University, Scotland

\section{John M Davis}

School of Education, University of Strathclyde, Scotland

\section{Luke J Addison}

Institute of Education, Community and Society, University of Edinburgh,

Scotland

\begin{abstract}
This article highlights an action research project that sparked transformation regarding how early years practitioners documented children's learning. The dominant discourse of standardisation and narrowing of early childhood education, encapsulated in the Organisation for Economic Cooperation and Development's International Early Learning Study, has resulted in the 'shaping' and 'testing' of young children around the globe. The OECD has become very interested in early childhood education and is a very instrumental player today (Moss, 2018). Consequently, the testing of young children has been instigated by governments to ensure children gain the accepted knowledge, skills and dispositions required to be successful learners.

Situated within this context of testing and standardisation, this article will share knowledge gained from a small action research project that took place in one Scottish early years setting. The study was stimulated by the early years practitioners of the setting, who strongly opposed the
\end{abstract}

\section{Corresponding author:}

Lynn J McNair, Institute of Education, Community and Society, University of Edinburgh, Edinburgh, EH8 8AQ, Scotland. Email: lynn.mcnair@ed.ac.uk 
'reductionist' formal 'tick-box' assessments produced by their local authority. These types of didactic formal assessments suggest that pedagogy is underpinned by a desire to tame, predict, prepare, supervise and evaluate learning. This article is of critical importance as it examines the imposition of didactic assessment from the practitioners' perspective. The practitioners in the study contested that 'tick-box' assessments diminished children's identities down to a list of judgements about their academic abilities, or lack thereof. The introduction of the 'tick-box' assessments presented a dilemma for the practitioners, in terms of the different views of the government and practitioners of what knowledge is worth knowing and what individuals and groups are able to learn. Many of the practitioners from the early childcare and learning setting positioned themselves and their work as being consciously different from what was going on in the wider sector. The early childcare and learning setting employed in this article introduced a new method to capture children's learning, which they named the 'Lived Story' approach. In this article, we argue that Lived Stories are a form of narrative assessment which are designed to track children's progress whilst respecting the complexity of their learning, their position within the learning process, the flow/fluidity of their ways of being and their ability to act in radical, creative and innovative ways. We conclude that by using 'Lived Stories' practitioners were able to lessen the surety of the language we use. The article highlights that as practitioners write Lived Stories and assess children's progress they are freed to use language such as 'wondering, puzzling, thinking, exploring'. In turn, we demonstrate that this language, and the ideas it enables, are on a continuum; a journey that spans a lifetime.

\section{Keywords}

Early childhood, assessment, revolutionary critical pedagogy, lived stories documentation

\section{Introduction}

In some early childcare and learning (ELC) environments children's play experiences are reduced to being regulated and assessed against the dominant discourses of child development and 'developmentally appropriate' tick-box practices (Dahlberg and Moss, 2010). Research has argued that this conventional 'transmissive' mode of gathering information from children is ultimately insufficient for understanding children and it can result in children feeling alienated from each other and becoming competitive (Moss, 2013). The study discussed in this paper was stimulated by practitioners of one Scottish ELC environment, who work under the aegis of their local authority. The practitioners' interest in being part of a research project stemmed from a feeling that they should resist, analyse and interrogate the top-down 'evaluation' and 'recording' process that some of the local authority middle managers (who had little experience of ELC) were seeking to impose in their setting.

The practitioners strongly opposed the 'reductionist' formal 'tick-box' assessments produced by their local authority, forefronting vital concerns that these types of didactic formal assessments foster a type of pedagogy that is underpinned by a desire totame, predict, prepare, supervise and evaluate learning (Moss, 2013: 40). They drew their critique from specific approaches to early learning which point out the pitfalls of trying to be reductionist when children's learning is episodic and uneven (Froebel, 1887). In so doing the practitioners illustrated a critical consciousness (Freire, 2018) which led them to question whether 
the 'tick-box' assessments diminished children's identities down to a list of 'normative' and disablist judgements about their academic abilities, or lack thereof (Alderson, 2008). Furthermore, it was argued that the 'tick-box' assessments compartmentalised curricular areas, which resulted in children being assessed against simplistic 'red', 'amber' and 'green' levels of learning.

In contrast, the practitioners questioned whether there were more interesting ways of thinking that position children as active agents, not subjects in their worlds. For example, they articulated their existing pedagogy in terms of Ingold's idea of 'wayfaring', where the child 'travels from place to place composing his thoughts along the way' (Ingold, 2011: 15). They suggested that this way of being, in learning spaces, enabled a more flexible approach to children's learning that began from the idea that adults and children should feel selfempowered to approach their learning as thoughtful, caring and intuitive human beings not machines, nor docile bodies that might be weighed like commodities.

The practitioners questioned whether the standardised tracking measures left any space for the children's individual perspectives, and whether these measures stifled a holistic view of development (Froebel, 1887; Tovey, 2020). The practitioners' concerns echoed with arguments in early childhood studies that we should understand children's learning journeys in terms of how they flow from what children can do - rather than in terms of how those journeys involve moments of arrival at specific developmental stations (e.g. Carr and Lee, 2019; Gallacher, in press).

The introduction of the 'tick-box' assessments became a significant antagonistic factor for the practitioners and presented a professional dilemma, that is, how to marry the different views of what knowledge is and what is worth knowing from their local authority with those from their professional registering body, their learning/reading and their colleagues' years of experience. In essence, the practitioners were concerned that the local authority were promoting dated and simplistic ideas about what individuals and groups are able to learn which contrasted with the practitioners' own professional codes of practice, academic learning and practical experience.

The practitioners were concerned with the potential negative impact of the top-down measures and questioned the local authority reductionist and managerialist approach. Elsewhere, such top-down processes have been referred to as 'a dictatorship with no alternatives' (Unger, 2005: 1). The practitioners did not reject the top-down processes out of hand. Rather, they were keen to rethink the top-down directive and examine the different ways they might capture children's learning. Rather than allowing their sense of well-being to be oppressed by the ruling ideology of 'tick-box' sheets (Dahlberg and Moss, 2010; Davis, 2011; Davis and Smith, 2012), the practitioners sought to examine whether a more flexible approach could be drawn out from the local authority's somewhat sterile, rigid and fixed advice.

In this article, we examine how this pedagogical resistance entailed a different approach to documentation at the research nursery - here called Lilybank. The practitioners named this nascent approach 'Lived Stories', building on research concerning 'Learning Stories' (Carr and Lee, 2019). When examining alternatives to the local authority's top-down methods the practitioners at Lilybank wondered whether, in building from and critiquing the principles of 'Learning Stories', they might be able to design a new and innovative method that would capture a holistic and more impressionistic portraiture of children's lives, whilst illustrating the complexity and richness of children's experiences (McNair et al., 2019). It may be important to add that 'Learning Stories' and 'Lived Stories' are similar yet different 
tools. Both involve a narrative observation and offer sophisticated analysis of that observation and a possible provocation; however, whilst 'Learning Stories' always focus on a 'learning' moment, 'Lived Stories' capture both learning moments and/or other pertinent moments that pick up on the civic life of the child. The Lived Stories approach allowed practitioners to document experiences from children's rich and complex lives without always needing to analyse those experiences along the lines of what the child supposedly learned.

\title{
Background
}

\section{Theoretical framework}

Building on the work of Paulo Freire's critical pedagogy, this article has been informed by an emerging body of educational theory and practice known as revolutionary critical pedagogy, a pedagogical orientation that is often called upon but rarely situated deeply in any theoretical depth (Ford, 2015). Revolutionary critical pedagogy is relatively new; however, McLaren (2005) provides a helpful definition:

\begin{abstract}
Revolutionary critical pedagogy begins with a three-pronged approach. First [practitioners] engage in a pedagogy of demystification centering around a semiotics of recognition, where dominant sign systems are recognised and denaturalised, where common sense is historicised, and where signification is understood as a political practice that refracts rather than reflects reality... This is followed by a pedagogy of opposition, where [practitioners] engage in analysing various political systems, ideologies and histories, and eventually [practitioners] begin to develop their own positions. Inspired by a sense of ever-imminent hope, [practitioners] take up a pedagogy of revolution, where deliberative practices for transforming the social universe of capital are put into practice. (McLaren, 2005: 59)
\end{abstract}

In response, revolutionary critical pedagogy is concerned with the political economy and critique of the material production of life. Practitioners in this study were interested in challenging wider social structures, for example not simply the practice of Lilybank, but that of the local authority itself, and therefore sought to investigate whether revolutionary critical pedagogy might provide a useful lens for understanding the logics and parameters of the study.

Revolutionary critical pedagogy has been characterised as both ontological and epistemological, as it is interested in understanding, constructing and transforming the world (Ford, 2015). The practitioners in this study were keen to take up the problem that some practices seek to iron out subjectivity by treating all children the same (Davis, 1998; Blaisdell et al., under review). In contrast, the practitioners were interested in opacity and uncertainty, in the unknown and the unknowable about children's lived experiences, all the while keeping in mind that each child is a unique being (Froebel, 1887).

The Lived Stories approach began from a perspective that there is no 'single truth' (Freire, 2018). Hence, the Lived Story approach did not seek to propose one fixed way of recording children's learning. Rather, it sought to act as a vehicle for uncovering different perspectives on children's experiences, aimed to tease out some of the intricacies and complexities of children's lives, and situated children's learning as an ongoing, critically engaging and reflexive process. In this sense, the practitioners employed revolutionary critical pedagogy as a basis from which to move towards conceptualising and portraying a new 
future and as a platform from which to examine the endless process of becoming that characterises ELC.

The research process enabled us to examine the political choices and ideological paths chosen by the practitioners, and build on the critical and reflexive tenants of Freirean pedagogy (McLaren, 2015). Whilst the practitioners did not, necessarily, set out to eliminate the local authority assessment practices, they were interested in meddling with them. Hence, this study provided an opportunity for a rapprochement, where practitioners sought to deconstruct unequal and exploitative practices and then reconstruct their approach in more just ways. As a result, the practitioners became 'individual and social agents', critically conscious, revolutionary and transformative leaders (Giroux, 2011: 13).

Scottish policy. This section examines the roots that underlie the development of testing and assessment regimes for the young children who attend Lilybank. The Scottish Government aims to give all Scottish children 'the best start in life' (Scottish Government, 2018/9). The dominant trends in the current social-political movement in Scotland have resulted in a focus on increasing children's time in ELC environments in order to assess and monitor their development. One of the strands of educational thought is increasing childcare is a step toward eradicating inequality (Scottish Government, 2017). This may illustrate that inequality and poverty continue to be major concerns, from educational administration to curricular design (Ford, 2015). Central to the endeavour to wipe out poverty is the Scottish Government's Blueprint for Expansion (Scottish Government, 2017). 'The Blueprint for 2020: The Expansion for Early Learning and Childcare' presents a vision of what could be. For example, in the Blueprint Action Plan, the first point of action states: 'We will strengthen the focus on child development within the assessment for all SVQ units for the Social Services (Children and Young People) group award' (Scottish Government, 2018: 3). While we refrain from going into too much depth here, the group award is the basic training needed for practitioners working with children, reinforcing the indivisibility of pedagogical practice and politics, as policy makers inform practitioners of what they need to learn within the realm of culture, ideas and knowledge (Kincheloe, 2008). Further, with child development being entrenched in basic training, there is little hope that it will be expanded on with knowledge of other disciplines, for example, the sociology of education (Willis, 1977). The early years expansion might not then be a liberatory vision, but one that confines practitioners to view the child through a narrow lens. Particularly so if newly trained practitioners view childhood as a progression of 'natural' stages, when childhood is neither universal nor natural (Norozi and Moen, 2016).

Furthermore, working under the erroneous assumption that there is a common understanding of 'quality' in ELC environments, the word 'quality' features 161 times across the two key documents of the Blueprint, which outlines the Scottish Government's vision of practice and impact (Scottish Government, 2017). The fundamental aim of the Scottish Government is that all ELC environments will be 'quality' ELC settings. Consequently, discourses on 'quality' pulsate through educational spheres, for example, practitioner educational programs and professional educational organisations; subsequently, the question asked by practitioners is 'What is meant by quality?'. The response elicits various and irreconcilable answers (Dahlberg et al., 2007), resulting in a myriad of debates occurring when practitioners are, most egregiously, not consulted on the various documents that inform their practice. Practitioners find themselves confused by the many contradictions of the countless iterations of the word (McNair and Addision, forthcoming). If top-down documentation does not make sense to the practitioners who need to interpret them into 
practice, the documents simply sustain and reproduce systems and relations of oppression. However, what McNair and Addison discovered was that if ELC environments are sites for oppression they can also be sites to disrupt oppression (Author and Author, forthcoming). That said, despite the Scottish Government's good intentions to offer children 'the best start in life' (Scottish Government, 2008), there appears to be a disconnect between the policy makers and practitioners and what is ultimately 'quality' practice. As Ford (2015: 25) argues, 'the nexus between education and politics has always been a central concern and debate for educators, educational theorists, researchers, and policymakers, dating back to Socrates and Plato'. In sum, it could be argued that, perhaps for good reason, the Scottish Government is a politics-pushing government who are strong defenders of, and advocates for, regulating and assessing children's learning, which may confirm that 'childhood is the most intensively governed sector of personal existence' (Rose, 1999: 124). This may suggest that we live in what Power (1977) calls an 'audit society', where the perspectives, ideas and values of the children, and practitioners working with children, are largely ignored.

\section{Research methods}

We begin this section with an anonymised illustrative example of a Lived Story. This story was written by a practitioner after a trip with four children to a local community project.

Dear Lily and Betty,

This morning I asked you if you would like to have a walk to the local Community Project, where a person called Tommy works with people to create things out of wood. Tommy and some people from the centre made the wooden toilet door, toilet seats, the reception counter, and shelves and library doors in our music room. We walked with Mischa and Kurt down the steep close, to the road below. You tested the acoustics underneath the bridge, using loud voices - 'Echo!' you shouted. We stopped at the site of the archaeological dig, which is much smaller than we've observed in the past. It was difficult to see but there were people with hard hats and high-vis jackets using tools to discover more about the remains of an old building under the ground; this small section had big girders around it. Most of the site has been filled in now. We wondered if a building might be made on top. You all looked fascinated by the digger in action. . . all except Mischa, who was asleep in the buggy! We crossed the road to the community centre. 'Look, there's writing on the wall', you said, Betty. It said 'Community Project'.

Unfortunately, we were not able to go upstairs to see Tommy at work. Instead, Tommy came downstairs to meet us. He had with him a big bag of wood off-cuts from some of the projects he and his students had been working on. There were pieces of different size, weight, shape, colour and texture. Tommy talked to us about the wood as we all touched the wood and loaded it into my bag at the bottom of Mischa's buggy. 'This one is smooth', observed Kurt, 'And this one is spikey!', noticing some splintery wood. 'This wood smells nice', you said, Lily, lifting a piece with the bark still on. Tommy told us of how he and some students will be going to Zambia, a country in Africa, to help make a school for girls who are 12 years and older, many of whom might otherwise not have the opportunity for learning in school. This school will be a safe space for Zambian girls to learn and play and continue to enjoy their childhood. We all thanked Tommy for our wood, and we left to walk back to Lilybank.

Today, I learned that you are a curious observer. You tested the acoustics by making your own sounds under the bridge. By exploring our local community, you have discovered the different roles people play and how they can help. You watched people at work within your community, in various jobs like archaeologists, machine operators, receptionists and carpenters. You smelled and handled different types of wood and you were able to describe with your words what you could smell, touch and see. Your questioning nature helps you to learn about the world around you. We never stop learning. Questioning and having varied experiences within your community encourages you to welcome diversity, 
understanding and inclusiveness. Exploring your community helps you to feel more connected to it and willing to participate in it. These concerns can extend to the global community, as you learn more. Perhaps you would like to make something with the wood that Tommy gave to us? What kinds of things would you like to create? There are musical instruments made from wood, you could continue with your explorations of sound with an instrument you have created. Structures, like houses and schools, can also be made of wood. The possibilities are as grand as your imagination.

Love Celina

This story was selected as an example because it illustrates many key qualities of the Lived Stories. The story is addressed directly to the children themselves. It is detailed and does not oversimplify the experience. It highlights children's rich connections to their communities and the long-term nature of those connections. However, this story also illustrates some ways that the Lived Stories were problematic, which will be discussed in more detail in this paper. For example, a large part of the story is dedicated to professional analysis and goes on to list specific links to the Scottish curriculum. The story is long and detailed, meaning it takes quite a bit of labour to write.

When the research project began, Lilybank practitioners had been experimenting with Lived Stories for about one year. The stories were written and uploaded onto an online platform where they could be shared with families. The research project, called Telling Life Stories, and funded by the Froebel Trust, sought to explore how the Lived Stories approach was working for children, families and staff, and to experiment even further with new methods of documenting children's experiences in keeping with Froebelian principles. The project was supported by researchers from the University of Strathclyde, who acted as support, co-enquirers and co-conspirators in the mission to deconstruct oppressive practices. We were guided by principles of action research which begin with 'hopes, dreams and desires', embrace uncertainties, and involve critical, political reflection on practices (MacNaughton and Hughes, 2008). The Telling Life Stories project had three broad phases. In Phase One, we enquired with children, practitioners and families about Lived Stories, including the online platform where they were hosted. Based on that learning, during Phase Two we experimented with alternative ways of telling Lived Stories, including audio stories and printed paper stories. Audio and print were chosen because we learned in Phase One that some practitioners found the long, written format of Lived Stories time consuming or inaccessible. We also learned in Phase One that children themselves were excluded from 'official' authorship of their own stories because of time, technology and access issues including the long, written format (Blaisdell et al., 2020). Finally, in Phase Three we enquired again with children, practitioners and families what Lived Stories, in their varied forms, meant to them.

The data we use in this paper came from mixed qualitative methods carried out by practitioners and university researchers, including one-on-one conversations with children, questionnaires for practitioners and parents, focus groups with practitioners and parents, and a group mind-mapping session with children. The data also include informal reflections from everyday dialogues about the Lived Stories project, emails sent by practitioners and families, and reflections by practitioners about how children interacted in everyday ways with their own Lived Stories. We analysed the data thematically and held several knowledge-exchange events during the project to foster dialectical knowledge generation between the researchers, practitioners and parents (Greenwood and Levin, 2007). In the following Findings sections, we discuss two key themes that arose from our enquiry about 
Lived Stories. First, that the Lived Stories were indeed seen by practitioners as a way to deconstruct and resist reductive, top-down assessment of children. Second, we examine the ways that the Lived Stories remained embedded in 'the system', meddling with - rather than eliminating - the local authority systems.

\section{Findings}

\section{Against reductionism: Lived Stories help deconstruct exploitative practices}

The belief that the Lived Stories enabled a step away from reductive methods of tracking and tick boxing was a common theme in the data from all three phases of the project. As previously discussed, the term 'Lived Stories' had evolved at Lilybank from the canonical term 'Learning Stories' (Carr and Lee, 2019). The terminology of 'Lived Stories' seemed to capture the more fluid and liberatory nature of what practitioners wished to document. For example, in their questionnaire, one practitioner said, 'I think it is wonderful that we are trying to think out the box and step away from tracking our children'. Both practitioners and parents agreed that the Lived Stories were preferable to the other methods of tracking available on the online platform. One such method was a system of tabs on each child's online page. Each observation uploaded to the platform had to be categorised into a curricular area, organised under its own separate tab. During the parent focus group in Phase One, one parent deconstructed the curricular area tabs, claiming that they created false divisions in children's experiences by forcing staff to decide what tab something belonged to (i.e. baking). In reality, the parent argued, baking 'is a bit of everything because that's what this early years is about, it's a bit of everything'.

As this quote illustrates, the curricular tabs in the online system were not seen as a neutral technology. Instead, the tabs forced a particular way of writing about children and categorising their lives in fragmented ways. It was not only the tabs that were incompatible with Lilybank values. Another reductive technology - the 'traffic light system' - was taken apart by a practitioner. The online system prompted practitioners to label children's progress in particular curricular areas as red, amber or green. The traffic light system was optional and practitioners at Lilybank bypassed it when uploading observations. However, the practitioner noted that, once again, the traffic lights were not a neutral feature of the online technology. Instead, they argued that the traffic lights created a deficit view of children: 'I dislike the traffic lights system of assessment, particularly as Froebelians celebrate what children can do, rather than what they can't' (Staff Questionnaire, Phase One). Finally, the Lived Stories also offered a way to contest reductive, linear visions of human learning and development. In the words of one practitioner, their ideal system of documentation would include lots of different voices about children's lives:

Something where there is more of a dialogue between all those involved in a child's life including the child themselves and their friends [...]

It does not need to be chronological. Our learning does not take place in a tidy path.

(Staff Questionnaire, Phase One) 
As this quote illustrates, Lived Stories seemed to offer a documentation approach that celebrated difference, multiple perspectives and fluidity, in contrast to the reductive technologies such as the curricular tabs and the traffic lights.

Another way that Lived Stories contested reductive methods of tracking children's development was the emotional connection fostered in the stories. Lived Stories were seen by practitioners as rich, detailed and specific to each child, 'personal and meaningful because of the relationships between staff and family and child' (Staff Focus Group, Phase One). Rather than creating a false 'objective' distance, Lived Stories were openly about creating a feeling of belonging and love. As one practitioner wrote, 'I like the "nothing about me without me" feel of things' (Staff Questionnaire, Phase One). They went on to say that by writing Lived Stories addressed directly to the child, they felt more accountable and personally connected to their writing, rather than adopting a pseudo-scientific 'neutral' approach to writing observations. Once again, that personal connection was a core element of the Lived Stories, as expressed by a practitioner during Phase Three. When asked how they felt when creating a Lived Story, they responded:

I feel very relaxed and calm. I have feelings that I'm writing about that I know very well, I feel confident and I see the person, the child exactly in front of me. I'm creating a lived story with fresh memories, with passion and love. It's about emotion, feelings and real person. (Staff Questionnaire, Phase Three)

As this quote illustrates, for some practitioners Lived Stories allowed them to express their respect for children's humanity and their differences as people - 'the child exactly in front of me'. At the same time, the quote suggests a respect for the practitioner's own humanity through their connection, passion and love for the child. Another practitioner said that the Lived Stories made them feel proud of themselves, and that their professional knowledge was being respected.

\section{'We don't like tracking, but. . .': Lived Stories embedded in the reductive system}

Rather than perpetuating reductive approaches to labelling and categorising young children's experiences, Lived Stories seemed to offer more space for fluidity and emotional connection. Practitioners felt the stories acknowledged the complex humanity of children as well as their own humanity. However, there were also tensions around the ways that Lived Stories sat within the wider system of early years regulation in Scotland. In particular, practitioners raised questions about the role of professional analysis and professional language in the stories, asking who the Lived Stories were really for. For example, two practitioners specifically interrogated these questions in slightly different ways:

I think we need to think about who we're writing them for, I mean, are we writing them for us as practitioners like 'oh, look what I can do'... or are we writing them for the child [...] Ultimately, I think we're probably doing it for parents.

(Staff Focus Group, Phase One)

Sometimes I feel it's too much me in the child's observation. We are using a lot of our thoughts and comments. 
(Staff Questionnaire, Phase One)

In separate writing (Blaisdell et al., in review), we have analysed the role of children as authors of their own Lived Stories, finding that they were often excluded except as subjects of the stories. Although all practitioners in the study valued dialogue, multiple voices and particularly the voices of children, in practice it was the practitioner voice that dominated the stories. In that writing, we describe the technological as well as the conceptual barriers to children's inclusion as authors, including 'rubbish WiFi' at the nursery that meant many practitioners wrote stories at home, practitioners not wanting to impose their own agenda on children's time at nursery, and the long narratives of Lived Stories taking a long time to write. In the quotes from practitioners above, another dimension of authorship begins to appear - the question of who the Lived Stories are for in the first place. As the first practitioner notes, the stories could potentially have an element of professional display ('look what we can do'). The second practitioner raises a connected issue - whether the Lived Stories are told 'too much' from the practitioner point of view.

These quotes hint at the ways that Lilybank practitioners were still embedded in a reductive system of assessment. For example, when asked what concerns they had about the research project and Lived Stories, one practitioner responded, 'I don't know how well all of this can relate to the requirements of the curriculum and the meeting of standards!' (Staff Questionnaire, Phase One). Here, the practitioner is specifically locating the Lived Stories within the particular requirements of the Scottish system. This was echoed by a parent at the focus group, who noted differences in what kind of text were in the Lived Stories:

Researcher: Sometimes the staff are finding that they need to put in these phrases...

Parent One: Oh, yeah.

Researcher: ...that maybe don't have any meaning for parents, certainly if you don't have any kind of early years background.

Parent One: There's a part of the text that I feel sometimes isn't actually for me but it's for that system of like...certainly from our entries, towards the end there's usually a paragraph that goes like 'and this, you know, meets Froebel's view of, you know, outside hands-on on learning... da da da da da'. It actually repeats in quite a lot of the entries and I know that's the kind of learning bit.

(Parent Focus Group, Phase One)

Here, this parent has focused in on several key issues. First, they identify bits of text that are the 'learning bit' - the professional analysis, and point out that it can be rote, with the same text copy/pasted into different entries about her child. Second, the parent notes that this text 'isn't actually for me', but is for 'that system'. Later, both parents in the focus group argued that there was a tension between the 'heartfelt' nature of the Lived Stories and the labelling of certain experiences as types of learning, which they saw as box-ticking exercises.

This tension is key for early years practitioners interested in pedagogical resistance to oppressive systems of domination and control in early years. Although the Lived Stories 
were, in many ways, beloved by practitioners and seen as a liberating practice as compared to the curricular tabs and tick-box traffic lights, the stories remained embedded in the relations of power in the Scottish system of quality assessment and tracking children's learning. For example, during the parent focus group, a member of the leadership team at Lilybank explained why the professional analysis was needed. They recalled that two years prior, during an inspection, ${ }^{1}$ the inspectors had read some of the early Lived Stories and 'ripped the staff up', saying 'very nice, but so what' and said none of the observations was worth anything. As this quote suggests, the professional analysis in the Lived Stories was a way of playing the game. Other ways that Lived Stories were connected to playing the game were by one of the managers using the online journals behind the scenes as evidence of good practice, explicitly linking the Lived Stories to Scottish curriculum and policy goals (Staff Focus Group, Phase One). This was described as a way of shoring up the nursery's position in the sector as a place where children experienced rich, child-led environments rather than explicit planning and direction from adults. The Lived Stories, therefore, could be wielded as tools within the Scottish system but did not actually free practitioners, parents or children from that system.

\section{Discussion}

The revolutionary critical pedagogy portrayed by the practitioners in Lilybank proffers an example of how passionate, caring practitioners can do more than simply change practice; they can challenge exploitative and oppressive directives. 'This is, after all, the aim of revolutionary critical pedagogy: to understand exploitation and oppression in order to rid the world of both and to create a world that we actually deserve' (Ford, 2015: 205). There is nothing inherently revolutionary about simply complaining about, or denunciating, educational directives that do not make sense to practitioners in practice (e.g. tick boxing children's rich experiences); it is the doing, the compounding, the defeating of those directives, that makes the difference. It is incompatible with revolutionary politics to do nothing (McLaren, 2005, 2015). What is being suggested here is that, when problems arise in educational spheres, practitioners should, individually or collectively, find ways to articulate their concerns. This may not be easy initially, but the alternative of not doing anything is not the answer. The prerequisite for political action emerged from a top-down tick-box assessment tool that the practitioners could not live with. Thus, some form of action was necessary.

As said, many practitioners positioned themselves and their work as being consciously different from what was going on in the wider sector or, to be most fair, there seemed to be an ethical dimension to this, a thoughtful conviction that this was the right way to be working with young children. However, the practitioners admitted that it was not an easy task to challenge their local authority/policy makers - the conflict, at times, caused the practitioners to feel stressed and question their actions; after all, they needed to continue to be in employment. Nonetheless, they explained that what they were doing was for immense public good and, consequently, they would continue to challenge exploitation and domination. The practitioners became stronger during this process, both personally and professionally. They agreed that being subsumed within a like-minded team made their political action more tenable, as they collectively recoiled from and denounced specific topdown directives. Consider again the work of McLaren (2005): 'eventually [practitioners] begin to develop their own positions. Inspired by a sense of ever-imminent hope' (2005: 59). It became clear that the practitioners, who were oriented toward the abolition of 
reductionist methods, saw themselves as change agents, and had a sense of belief that they could make a difference. This was especially evident as the practitioners argued that, despite being under the aegis of their local authority and the consequent tensions they endured, they could not jettison their ideas to capture the complexity of the experiences lived by the children and move toward reductionist, narrow, simplistic methods of recording.

Consequently, the practitioners illustrated revolutionary critical pedagogy in several ways, the first being that they embraced the idea of education as political practice, acknowledging that collectively they were 'in one way or another committed to the imperative of transforming the larger social order in the interest of justice, equality, democracy, and human freedom' (Biesta, 1998: 499). They conceded that the key idea of their pedagogical resistance transpired from a disregard of reductionism in children's experiences and willingness to try something new, and that they were keen to challenge top-down directives in order to enhance the quality of children's lived experiences. Thus, the 'Lived Story' project galvanised the practitioners into creating a new method that challenged reductionist ways of working, and confronted the de-homogenising of the child, resulting in 'micro strategies of resistance' (Ellsworth, 1989).

Revolutionary critical pedagogy is dedicated to the fight for alternative methods; successively, the 'Lived Story' project emerged from avowed intentions, by practitioners, to design a tool that captured children's meaningful experiences through participatory and democratic processes. As said, this was not an easy task - challenging oppressive ideas is one thing; moreover, practitioners 'are not necessarily free from their learned and internalised oppressions', and therefore they may have influenced the process (Ellsworth, 1989: 308). For instance, at times, the practitioners may have helped place children's lived experiences in perspective which may have enabled subjugated knowledges to emerge. Subsequently, we do not wish to exaggerate by suggesting that the desire for participation was met fully, as some children were not aware of the 'Lived Stories' until they were shared during the research (De Jaegher and Di Paolo, 2007). However, in similar thinking to Freire (2018), it was important to the practitioners that the experiences children had were rooted in their daily lives and if practitioners were recording these experiences the recordings needed to be orientated toward the transformation of the children's lives and experiences in a way that was meaningful to the child (and their families). Hopes for transformation include listening to the rendered illustrations shared by children and practitioners (and parents) as they engage in and with the vivid lives of children.

Judicious to revolutionary critical pedagogy is that difference is celebrated; the practitioners in this study illustrated that considerations of difference were absolutely central, and tightly wedded, to their pedagogical approach to documentation. The 'Lived Story' approach deconstructs the conventional measurement tool where all children are expected to do everything at the same time. The 'heartfelt' nature of the Lived Story approach enabled practitioners to recognise the different needs of each child and provide an opportunity to develop closer contact with families. Finally, but very importantly, the 'Lived Story' approach is not an inert approach; it will grow and adapt as the practitioners continually develop their skills in documenting the rich lives of children, and narrating the captivating stories that emerge. 


\section{Acknowledgements}

Thank you to the children and adults of Lilybank. We would also like to acknowledge the anonymous reviewers for their constructive and detailed feedback.

\section{Funding}

This work was supported by the Froebel Trust under Grant RCH-35-2017.

\section{ORCID iD}

Lynn J McNair (D) https://orcid.org/0000-0002-5730-0704

\section{Note}

1. Education Scotland and the Care Inspectorate are the regulatory bodies in Scotland. Both work together to evaluate services for children aged 0 to school age.

\section{References}

Alderson P (2008) Children's Rights: Exploring Beliefs, Principles and Practice. London: Jessica Kingsley Publishers.

Biesta G (1998) Say you want a revolution. . Suggestions for the impossible future of critical pedagogy. Educational Theory 48(4): 499-510.

Blaisdell C, McNair LJ, Davis J M and Addision LA (under review). 'Exploring 'Lived Stories' : The paradigms, theories and methodologies of living alongside young children. Submitted for the EECERA conference 2020.

Carr M and Lee W (2019) Learning Stories in Practice. Thousand Oaks: SAGE.

Dahlberg G and Moss P (2010) Introduction by the Series Editors. In: Lenz Taguchi H (ed) Going Beyond the Theory Practice Divide in Early Childhood Education: Introducing an Intra-active pedagogy. London: Routledge, pp. 10-12.

Dahlberg G, Moss P and Pence A (2007) Beyond Quality in Early Childhood Education and Care (2nd ed.). London: Routledge.

Davis J (2011) Integrated Children's Services. London: SAGE.

Davis J and Smith M (2012) Working in Multiprofessional Context. London: SAGE.

De Jaegher H and Di Paolo E (2007) Participatory sense-making: An enactive approach to social cognition. Phenomenology and the Cognitive Sciences 6(4): 485-507.

Ellsworth E (1989) Why doesn't this feel empowering? Working through the repressive myths of critical pedagogy. Harvard Educational Review 59 (3): 297-324.

Ford DR (2015) Pedagogy, social transformation, and space: Toward a revolutionary critical pedagogy for space. PhD Thesis, Syracuse University, USA.

Freire P (2018) Pedagogy of the Oppressed. New York: Bloomsbury Academic.

Froebel F (1887) The Education of Man (Translated by Hailmann WN). New York, London: D. Appleton Century.

Gallacher L (in press) From milestones to wayfaring: Geographic metaphors and iconography of embodied growth and change in infancy and early childhood. GeoHumanities.

Giroux H (2011) On Critical Pedagogy. New York: Continuum.

Greenwood DJ and Levin M (2007) Introduction to Action Research: Social research for Social Change (2nd ed). London: SAGE.

Ingold T (2011) Redrawing Anthropology: Material, Movements, Lines. Surrey: Ashgate Publishing. Kincheloe J (2008) Critical Pedagogy Primer. New York: Peter Lang. 
MacNaughton G and Hughes P (2008) Doing Action Research in Early Childhood Studies. Maidenhead: Open University Press.

McLaren P (2005) Capitalists and Conquerors: A Critical Pedagogy against Empire. New York: Rowman and Littlefield Publishers.

McLaren P (2015) Life in Schools: An Introduction to Critical Pedagogy in the Foundations of Education (6th ed.) Boulder and London: Paradigm Publishers.

McNair LJ and Addision L (forthcoming) Quality for whom? - Perspectives on 'quality' in the context of the Scottish ELC expansion. Submitted to GER (2020).

McNair L, Cameron I and Gilbertson L (2019) Adult roles in support of early childhood play, encouraging sensitivity to the individual and reflexive approaches. Scottish Educational Review 51(2): 43-49. Available at: http://www.scotedreview.org.uk/online-content/2019/512/

Moss P (2018) Alternative Narratives in Early Childhood: An introduction for students and practitioners. London: Routledge.

Moss P (2013) Early Childhood and Compulsory Education: Reconceptualising the Relationship. London: Routledge.

Norozi SA and Moen T (2016) Childhood as a social construction. Journal of Educational and Social Research 6(2): 75-80.

Power M (1977) The Audit Society: Rituals of Verification. Oxford: Oxford University Press.

Rose NS (1999) Governing the soul: the shaping of the private self. London: Free Association Books.

Scottish Government (2017) A Blueprint for 2020: The Expansion of Early Learning and Childcare in Scotland, Quality Action Plan. Edinburgh: Scottish Government. Available at: https:/www.gov. scot/binaries/content/documents/govscot/publications/strategy-plan/2017/10/blueprint-2020-expan sion-early-learning-childcare-scotland-quality-action-plan/documents/00526782-pdf/00526782-pdf/ govscot\%3Adocument/00526782.pdf accessed 18 November 2020.

Scottish Government (2018/9) Delivering for Today, Investing for Tomorrow. Edinburgh: Scottish Government. Available at: https://www.gov.scot/binaries/content/documents/govscot/publica tions/strategy-plan/2018/09/delivering-today-investing-tomorrow-governments-programme-scot land-2018-19/documents/00539972-pdf/00539972-pdf/govscot\%3Adocument/00539972.pdf accessed 18 November 2020.

Scottish Government (2017) The Blueprint for 2020: The expansion of early learning and childcare: Action plan. Report, October. Available at: http://www.gov.scot/binaries/content/documents/govs cot/publications/strategy-plan/2017/10/blueprint-2020-expansion-early-learning-childcare-scot land-quality-action-plan/documents/00526782-pdf/00526782-pdf/govscot\%3Adocument/ 00526782.pdf (accessed 22 August 2020).

Tovey H (2020) Froebel's Principles Practice Today. London: The Froebel Trust. Available at: https:// www.froebel.org.uk/uploads/documents/FT-Froebels-principles-and-practice-today.pdf accessed 18 November 2020.

Unger R (2005) What Should the Left Propose? London: Verso.

Willis P (1977) Learning to Labor: How Working-class Kids Get Working-class Jobs. New York: Columbia University Press.

\section{Author Biogrpahies}

Lynn J McNair is Head of Cowgate Under Fives Centre in Edinburgh, Scotland, and is a Senior Teaching Fellow at the University of Edinburgh. Lynn has almost 40 years experience working in Early Years Education and was awarded an OBE for services to Early Education in 2009. Lynn is a trained Froebelian, attaining her certificate at the Froebel Institute, Roehampton University, London, UK. She is an award-winning author. Finally, Lynn would say her passion for egalitarianism, emancipation, democracy and a belief that children are rich, active, resourceful beings came from being a mother to Kurt and Mischa; 
and what she learned as she observed them playing freely as children. This way of being with children, trusting in them in their abilities and capabilities is where she puts her energy into her work with children today.

Caralyn Blaisdell is a researcher and lecturer in Initial Teacher Education at Queen Margaret University in Scotland. Her research focuses on young children's rights, and how those rights are lived, negotiated and made real. She also works on research methods and ethics with children.

John M Davis is a Professor of Education at the University of Strathclyde. John previously worked at the University of Edinburgh as director of the BA in Childhood Studies, Head of Department of Educational Studies and subsequently, Professor of Childhood Inclusion. He has also been chair of the Childhood Practice development group which develop the innovative qualification for managers/leaders of early learning, out of school, childminding, family support and related services. His research focuses on childhood, disability, inclusion and social justice and seeks to support children, young people, parents and professionals to develop creative and innovative solutions to their life issues. John's research has utilized participatory childhood research methods to support children and young people to gain recognition for their perspectives concerning inclusion, social justice and integrated working. His collaborative knowledge exchange projects have supported children, families and professionals to develop contemporary, innovative and inclusive children's services. His work has also examined international approaches to multi-professional working and increased our understanding of the factors that foster creative and innovative learning.

Luke $\mathbf{J}$ Addison is a Teaching Fellow in Childhood Practice at the University of Edinburgh, teaching a range of courses across early years management, leadership, and children's rights. Luke is also a PhD student researching children's perspectives of sustainability and how Froebelian pedagogies can underpin a radical ecologising of early years education. Luke developed an outdoor, nature kindergarten from inception and nurtured this over a decade into an award-winning, international example of best practice. Luke has a passion for radical change in education through critical, sustainable, ethical pedagogies that embrace complexity, welcome 'other' knowledge and decentre the human. 